\title{
EARNINGS RESPONSE COEFFICIENT : CSR DISCLOSURE, AUDIT COMMITTE AND DEFAULT RISK
}

\author{
Miftah Kamal Nuriyanto*1, Annisa Nurbaiti ${ }^{2}$, Wiwin Aminah $^{3}$ \\ Telkom University, Indonesia \\ malkamal@Student.telkomuniversity.ac.id ${ }^{* 1}$, annisanurbaiti@telkomuniversity.ac.id² \\ Wiwinaminah@telkomuniversity.ac.id ${ }^{3}$
}

\begin{abstract}
An investor needs to collect financial information as a matter of consideration in making his economic decision by using earning response coefficient. The value of ERC that appears will be goodnews when the value is raised high and will be badnews when the value of ERC is low. This research aims to test how the influence of CSR Disclosure, Audit Committee and Default Risk to Earnings Response Coefficient. The research was conducted on the basic and chemical industry sectors list on the IDX from 2015 to 2018. By using pusposive sampling technique obtained as many as 23 companies with 4 years observation time obtained amount 92 observations. Outliers performed 11 observations so that the number of observations used was 81 observations with Non-probability sampling. This research uses a descriptive statistical analysis technique and a data panel regression method. Results showed that the CSR Disclosure, Audit Committee, Default Risk simultaneously, has an influence on the earnings response coefficient. Partially, audit committee has a negative affect on the earnings response coefficient. While the CSR Disclosure and Default Risk has no affect on the earnings response coefficient.
\end{abstract}

Keywords : Corporate Social Responsibility, Audit Committe, Default Risk, Earnings Response Coefficient

\section{INTRODUCTION}

The continuity of activities that occur in the capital market,will not happen without the role of an investor. As an effort to achieve his goals, an investor needs relevant, reliable, accurate, updated and complete information. This information is to be used in assessing, weighing and determining its economic decisions appropriately and gives them a satisfying impression Information in the form of corporate profits is collected through the income statement of the company which involving all components of the company such as Board of Commissioners, management and shareholders. that will determine the quality of corporate profit information, (Hartanto \& Wijaya, 2019), (Reyhan, 2014). Based on the signal theory, the company will signal the stakeholder either the internal or external parties of the company. This signal is information on important records about what the company has done in the past in realizing the wishes of the owner, (Tuhasanah \& Nikmah, 2017). Corporate Management conducts a report drafting involving all components of the company such as Board of Commissioners, management and shareholders making the best possible decision to sell the company's value and quality, (Natalia \& Ratnadi, 2017). Profit information that is deemed to contain good news will lead to a positive market reaction which means the actual return of the stock is greater than the expected return. Investors will compete to buy stocks sold by this company. However, if the information contained in bad news will cause negative market reaction, it means that the actual return on stock is smaller than the expected return. Investors will immediately remove the shares from the company, (Haryanto, 2018). However, the information obtained from the profit has not been enough as the basis for investor decision 
making. In order to avoid untrue assumptions and avoid the possibility of falsehood information need to be done other considerations to determine and predict the purchase of a company's share is called Earnings Response Coefficient, (Natalia \& Ratnadi, 2017). In this study used Earnings Response Coefficient as the measure of the market response in receive the information contained in the profit information. According to Scoot (2009), Earnings response Coefficient is the size of an abnormal return (the difference between expected return and actual return) and securities in response to the Unexpected Earnings component (the difference between the expected Earnings and the actual Earnings) reported by the company that issued the securities. According to Suwardjono (2005), an event (in this case a profit announcement) can be recognised as having credible information if the incident affects the recipient's belief (capital market) and subsequently triggers certain actions. In other words, the researcher argues that the response that appears will different from one to another due to the value of information that is contained in the company's earnings announcement. Strong market response can be reflected by the high value of ERC. In other words if the information is good and credible then the reaction of the market is also strong. Conversely, if the information contained in the announcement of the earnings is low and can't be trusted then the reaction will be weak. The phenomenon of the company's profit announcement becomes the focus of investors who can change the market conditions. The market built a paradigm of hope about profit and return that will be received by them. The difference between expected profit and the actual profit announced is Unexpected earnings. With the emergence of unexpected earnings will affect the price of shares and then will affect the return of its shares, (Maharani, 2014)
In making economic decisions the investors do need information about the company's financial condition but not only the information of profit but rather a lot of other information, (Mulyani, et al. 2007). To avoid the risk of incorrect decision and avoid the risk of other losses in investments, an investors should also pay attention to other matters not raised in the profit information such as the disclosure of Corporate social responsibility, Audit Committee and Default risk which become independent variables in this study, (Fauzan \& Purwanto, 2017), (Simamora \& Herawaty, 2019), (Aryengki, 2016), (Ratnasari, 2017).

The Corporate Social Responsibilty (CSR) disclosure is still one of the defining factors that can change the ERC. CSR disclosure is considered to affect the market reaction during the implementation of the company carrying out its responsibilities and reveal it on Annual report which contains Three major components of disclosure namely Economics, environment and social, (Sulung, 2019)

A company that discloses CSR aims to reduce the unbalanced and minimize unaccuracy Information from the limited earnings announcement. In the research of Fauzan \& Purwanto (2017), said if the company that conducts the CSR disclosure hopes the investors will use the information from the disclosure of CSR and profit information to help them in making decision, then responds quickly to earnings announcements so it will increase the ERC value.

Audit committee also became another factor that could affect the Earnings Respone Coefficient, (Aryengki, 2016). The establishment of an audit committee is an implementation of good corporate governance. In the formation of the audit Committee there are a minimum of three independent persons, including an audit committee with accounting skills. In addition, the Audit committee is headed by a person 
from an independent commissioner, (Reyhan, 2014).

The audit committee is established to assist the Board of Commissioners to fulfill overall supervision responsibilities for all of management and auditors of the company. The audit Committee plays a role in influencing the quality of financial statements which will be the source of information for investors in making decisions. Investor as a person who doesn't know the internal company requires performance information through the perception of Audit Committee, (Aryengki, 2016).

Default Risk is a risks that are specific to each company And thus have the possibility to influence the profit and return of company shares. According to Ratnasari et al. (2017) Default Risk is the risk of failure that may be experienced in paying a loan or interest in a company. Investors tend to look at companies that have prospects for growing high enough and not many use of debt for company operational activities.

Default Risk is measured by leverage that measures the amount of possible failure rates of the company in paying the loan or interest of the total debt or total assets. Default risk becomes one of the factors consideration of invetation by looking at the leverage value that arises from the company's earnings announcement. If the leverage indicates a high value it will lower the ERC value. Conversely, if the leverage indicates a low value then it will raise the ERC.

\section{METHODS}

This research aims to examine and analyze the influence of CSR Disclosure, Audiit Committe, and Default Risk on Earnings Response Coefficient. Based on the purpose of this research this research uses quantitative methods. The population used in this research is a manufacturing company of basic and chemical industry sectors listed on the Indonesia Stock Exchange (IDX) from 2015 to 2018. Sampling method uses purposive sampling techniques with criteria (1) companies that provide annual financial statements, (2) companies listed consistently on the Indonesia Stock Exchange in the research period and (3) Companies reporting Corporate Social Responsibility activities during the research period in annual report. By using pusposive sampling technique there are 23 companies with four years observation time, obtained amount 92 observations. Outliers performed 11 observations so the number of observations used was 81 observations. In testing hypothesis used data panel regression method with the following equation.

$E R C=\alpha+\beta_{1} X 1+\beta_{2} X 2+\beta_{3} X 3+\varepsilon$

Keterangan :

$$
\begin{array}{ll}
\text { ERC } & =\text { Earnings response coefficient } \\
\alpha & =\text { Constant } \\
\text { X1 } & =\text { Corporate social } \\
& \text { responsibility index }(X 1) \\
X 2 & =\text { Audit Committe }(X 2) \\
X 3 & =\text { Default risk }(X 3) \\
\beta_{1}, \beta_{2}, \beta_{3} & \text { Partial Regression Coefficient } \\
\varepsilon & =\text { Error Rate }
\end{array}
$$

\section{Earnings Response Coefficient}

Earnings Response Coefficient measured by doing a regression between the value of Cummulative Abnormal Return with the value of unexpected earnings, with the following to Hartanto \& Wljaya (2019) and Sulung (2019) ERC measured by steps :

1. Measuring the value of actual retun and market return

$$
\mathrm{Rx}, \mathrm{t}=\frac{P x, t-P x, t-1}{P i, t-1}
$$

$\mathrm{Rx}, \mathrm{t}=$ Actual Return $\mathrm{x}$ company shares at $t$ (days)

$P x, t=$ closing price $x$ company at $t$ (days)

$\mathrm{Px}, \mathrm{t}-1=$ closing price $\mathrm{x}$ company at $\mathrm{t}-1$ (days)

$$
\mathrm{RM}, \mathrm{t}=\frac{I H S G t-I H S G t-1}{I H S G t-1}
$$

$\mathrm{Rm}, \mathrm{t}=$ Market Return at $\mathrm{t}$ (days) 
IHSGt = Composite indeks at t (days)

IHSGt-1 = composite indeks at $\mathrm{t}-1$ (days)

Measuring the value of abnormal return

$$
A R x, t=R x, t-R M, t
$$

$\mathrm{ARx}, \mathrm{t}=$ Abnormal Return $\mathrm{x}$ company at $\mathrm{t}$ (days)

$\mathrm{Rx}, \mathrm{t}=$ Actual Return shares $\mathrm{x}$ company at $\mathrm{t}$ (days)

$\mathrm{RM}, \mathrm{t}=$ Market Return at $\mathrm{t}$ (days)

Measuring the value of cummulative abnormal return

$$
\text { CARx, } \mathrm{t}_{(-3 .+3)}=-3 \sum^{+3} \text { ARx,t }
$$

CAR $x, t_{(-3 .+3)}$ : Cummulatice abnormal return $x$ company at event window $t-3$ to $t+3$ (year) $-3 \Sigma^{+3} A R x, t:$ Abnormal return $x$ company at event window $t-3$ to $t+3$ (year)

CAR at earnings announcement measured in event window as long as 7 days ( 3 days before closing price, at the closing price and 3 days after closing price), at this time is considered able to detect the abnormal return as aresult of the earning announcement (Natalia \& Ratnadi, (2017).

2. Measuring the value of Unexpected earnings.

$$
\text { UEx,t }=\frac{(\text { EATt }-E A T t-1)}{E A T t-1}
$$

UEx,t = Unexpected Earnings $\mathrm{x}$ company at $t$

EATt = Earnings Per Share $\mathrm{x}$ company at $t$ (year)

EATt 1 = Earnings Per Share $\mathrm{x}$ company at $\mathrm{t}-1$ (year)

Measuring the Earnings response coefficient

$$
\text { CARx, } t=\alpha 0+\alpha 1+\mathrm{UEx}, t+\mathrm{e} i, t
$$

$\mathrm{CARx}, t=$ Cummulative Abnormal

Return $\mathrm{x}$ company at $\mathrm{t}$ (year)

$\alpha 0=$ Constants $\alpha 1=$ Earnings Response Coefficient

UEx,$t=$ Unexpected Earnings

$\mathrm{e} i, t=$ Error Component

\section{Csr Disclosure}

CSR Disclosure as following to Wahyudi \& Kadir (2019) measured by

$$
\text { CSRDIj }=\frac{\sum x i j}{n_{j}}
$$

CSDlj : Corporate Social Responsibility Disclosure Index i company

$\mathrm{Xij}=$ Number disclosure of i company, rate 1 if item disclose, rate 0 if item undisclose

$\mathrm{Nj}$ = Total disclosure for company as many as 91

\section{Audit Committte}

Audit committe as following to Farhan (2019) measured by

$$
\mathbf{A C}=\frac{\text { Expert Audit Committe Members }}{\text { Audit Committe Total in Company }}
$$

\section{Default Risk}

Deafult Risk as following to Ratnasari (2017) measured by using Leverage ratio as follows

$$
\mathrm{Lj}=\frac{T U_{j}}{T A_{j}}
$$

$\mathrm{Lj} \quad=$ Leverage Rate of the Company

TUj = Debt Total of the Company

$\mathrm{TAj}=$ Assets Total of the Company

\section{RESULTS AND DISCUSSION}

Descriptive statistic for the number of test sampels are 23 Company with four year period. then obtained 92 observation data. Outliers performed 11 observations so, the number of observations for this research used was 81 observations. The test includes testing minimum value, maximum value, mean value and Standard deviations. Descriptive statistic analysis result are as follows. 
Table 1. Result Of Descriptive Statistic Analysis

\begin{tabular}{cccccc}
\hline Variabel & $\mathrm{N}$ & Minimum & Maximum & Mean & $\begin{array}{c}\text { Std. } \\
\text { Deviasi }\end{array}$ \\
\hline $\begin{array}{c}\text { Earnings Response } \\
\text { Coefficient }\end{array}$ & 81 & $-0,313$ & 0,206 & $-0,007$ & 0,0783 \\
CSR Disclosure & 81 & 0,076 & 0,4505 & 0,229 & 0,083 \\
Audit Committe & 81 & 0,25 & 1 & 0,667 & 0,220 \\
Default Risk & 81 & 0,097 & 0,99 & 0,475 & 0,202
\end{tabular}

Source : Data that has been processed by the Author (2020)

Based on the information presented in Table 1, Earnings Response Coefficient variable obtained a minimum value of $-0,313$, obtained maximum value of 0,206 , obtained average value of $-0,007$ and obtained 0,00783 for Standard deviation value. Then, CSR Disclosure variable obtained 0,076 for minimum value, 0,4505 for maximum value, obtained average value of 0,229 and 0,083 for Standard deviation value. Audit Committe obtained minimum value of 0,25 , obtained maximum value of 1 , obtained average value of 0,667 , and 0,220 for standard deviation. Default Risk obtained minimum value of 0,097 ,

\section{Multicolinearity test}

Table 2. The Result Of Multicolinierity Test

\begin{tabular}{cccc}
\hline & $\mathrm{X} 1$ & $\mathrm{X} 2$ & $\mathrm{X} 3$ \\
\hline $\mathrm{X} 1$ & 1.0000 & -0.3223 & -0.2370 \\
X2 & -0.3223 & 1.0000 & 0.0508 \\
X3 & -0.2370 & 0.0508 & 1.0000 \\
\hline
\end{tabular}

Source : Eviews10 Processing (2020)

Based on the information presented in Table 2, obtained value of $0,3223,-0,2370$ and 0,0508 lower than

\section{Heteroskedasticity test}

Heteroskedastisity Test aims to detect whether the model has the similarity or absence of variance from obtained maximum value of 0,99 , obtained average value of 0,475 and 0,202 for standard deviation.

\section{Classic Assumption Test}

The purpose of this test is to determine the presence or absence of the symptoms of multicholinerality and the symptoms of heteroskedastisity in this research. Testing the classic assumption of this research using two test models, namely Multicoliniearity test and Heteroskedakticity test. Here are the result of Multicolinearity test. 
Table 3. The Result Of Heteroskedasticity Test

\begin{tabular}{cccc}
\hline Variable & Coefficient & Std. Error & Prob. \\
\hline C & 0.012976 & 0.012634 & 0.3076 \\
X1 & 0.012159 & 0.027495 & 0.6596 \\
X2 & 0.007089 & 0.010096 & 0.4847 \\
X3 & -0.015723 & 0.010725 & 0.1467 \\
\hline
\end{tabular}

Source : Eviews 10 Processing (2020)

Based on the information presented in Table 3, Obtained Probability value for every independent variables are greater than significant

\section{Data Panel Analysis}

\section{Regression Model Estimation} Chow Test

Table 4. The Result Of Chow Test

\begin{tabular}{lccc}
\hline Effects Test & Statistic & d.f. & Prob. \\
\hline Cross-section F & 2.19 & $(22,55)$ & 0.0099 \\
Cross-section Chi-square & 50.91 & 22 & 0.0004 \\
\hline
\end{tabular}

Source : Eviews10 Processing (2020)

Based on the information presented in Table 4, Obtained Probability of Cross-section Chi-Square value of 0,0004 lower than significant value of 0,05 , this shows that Fixed Hausman Test value of 0,05 , this shows that the data in this research are free from the symptoms of heteroskedasticity.

Table 5. The Result Of Hausman Test

\begin{tabular}{lccc}
\hline Test Summary & Chi-Sq. Statistic & $\begin{array}{r}\text { Chi-Sq. } \\
\text { d.f. }\end{array}$ & Prob. \\
\hline Cross-section random & 0.691769 & 3 & 0.8751
\end{tabular}

Source : Eviews10 Processing (2020)

Based on the information presented in Table 5, Obtained Probability Cross-section random value 0,8751 greater than significant value of 0,05, this shows that Random Effect
Effect Model greater method than Common Effect Model. Then, conducted Hausman Test. 


\section{Lagrange Multiplier Test}

Table 6. Lagrange Multiplier Test

\begin{tabular}{lc}
\hline $\begin{array}{l}\text { Null (no rand. effect) } \\
\text { Alternative }\end{array}$ & $\begin{array}{c}\text { Cross-section } \\
\text { One-sided }\end{array}$ \\
\hline Breusch-Pagan & 3.874916 \\
& $(0.0490)$
\end{tabular}

Source : Eviews10 Processing (2020)

Based on the information Model greater than Common Effect presented in Table 6, Obtained Model and mean regression method will Breusch-Pagan value of 0,0490 this be used in this research is Random mean lower than significant value of Effect Model.

0,05. This shows that Random Effect

\section{Coefficients of determinations and simultaneous F Test}

\section{Table 7. The Result Of Coefficients of determinations and simultaneous}

\begin{tabular}{ll}
\hline R-squared & 0.099198 \\
Adjusted R-squared & 0.064102 \\
S.E. of regression & 0.062533 \\
F-statistic & 2.826474 \\
Prob(F-statistic) & 0.044075
\end{tabular}

Source : Eviews10 Processing (2020)

Based on the information presented in Table 7, Obtained Probability (F-Statistic) value of 0,044 mean lower than significant value of 0,05 , this shows simultaneously, Independent variable CSR disclosure, audit Committee and default risk affect on the dependent variable earnings response coefficient. futher, coefficient of determinations value of 0,0991 , this shows that all of independent variables used is only able to explain Earnings Response Coefficient by $9,91 \%$. And amounted to $90,09 \%$ residual value described by other variables that aren't used in this research.

\section{Partial Test}

Table 8. The Result Of Partial Test

\begin{tabular}{ccccc}
\hline Variable & Coefficient & Std. Error & t-Statistic & Prob. \\
\hline C & 0.1293 & 0.0607 & 2.1303 & 0.0363 \\
X1 & -0.1664 & 0.1344 & -1.2376 & 0.2196 \\
X2 & -0.1440 & 0.0507 & -2.8376 & 0.0058 \\
X3 & -0.0081 & 0.0520 & -0.1561 & 0.8764 \\
\hline \multicolumn{5}{c}{ Source : Eviews10 Processing (2020) }
\end{tabular}


Based on the information presented in Table 8, the model analysis of data panel regressions in the research, it resulted in an equation is : $\mathrm{ERC}=0,1293-0,1664$ CSR Disclosure - 1,1440 Audit Committe - 0,0081 Default Risk $+\varepsilon$

Based on the information presented by Table 8 shows, that $\mathrm{X} 1$ variables obtained $-0,1664$ constants and probability value of 0,2196 greater than significant value of 0,05 , It shows that the CSR Disclosure has no significant effect on Earnings Response Coefficient. then it can be determined that the hypothesis $\mathrm{HO}$ is accepted and $\mathrm{H} 1$ is rejected. Then it shows the CSR Disclosure has no significant effect on Earnings Response Coefficient

Audit Committe variable obtained 0,1440 constants and The probability value of X2 Audit Committe is 0,0058 lower than significant value of 0,05 , It shows that the Audit Committe negatively effect on Earnings Response Coefficient. then it can be determined that the hypothesis are rejected. because it shows the Audit Committe has a negative effect on Earnings Earnings Response Coefficient.

Default Risk variable obtained 0,0081 constant and The probability value of X3 Default Risk is 0,8764 greater than significant value of 0,05 , It shows that the deafult risk has no effect on Earnings Response Coefficient. then it can be determined that the hypothesis $\mathrm{HO}$ is accepted and $\mathrm{H} 1$ is rejected. And it shows the default Risk has no effect on Earnings Earnings Response Coefficient.

\section{CONCLUSION}

Based on the analysis and the result of the test in the previous section. The conclusions are as follows : simultaneously, CSR Disclosure, Audit Committe and Default Risk variables affect on the Earnings Response Coefficient variable. While Partially, Audit Committe has a negative affect on the Earnings Response Coefficient. then, The CSR Disclosure and Default Risk variables has no affect on the Earnings Response Coefficient.

\section{REFERENCES}

Aryengki, R. (2016). Pengaruh Komite Audit, Kualitas Audit, Likuiditas

Dan Ukuran Perusahaan Terhadap Kualitas Laba. JOM Fekon Vol.3 No.1.

Fauzan, M., \& Purwanto, A. (2017). PENGARUH PENGUNGKAPAN CSR, TIMELINESS, PROFITABILITAS, PERTUMBUHAN PERUSAHAAN DAN RESIKO SISTEMATIK TERHADAP EARNING RESPONSE COEFFICIENT (ERC. DIPONEGORO JOURNAL OF ACCOUNTING ISSN (Online): 2337-3806 Vol.6 No.1, 1-15.

Hartanto, D., \& Wijaya, H. (2019). Faktor-Faktor Yang Mempengaruhi Earning Response Coefficient (Erc) Dengan Profitabilitas Sebagai Prediktor . Jurnal Multiparadigma Akuntansi, Volume I No. 2/2019, 344-354 .

Haryanto, M. (2018). Pengaruh Interaksi Corporate Social Responsibility dan Likuiditas Saham Terhadap Earnings Response Coefficient. JEMAP : Jurnal Ekonomi, Manajemen, Akuntansi dan Perpajakan ISSN : 2622-612X (MediaOnline) | Vol. 1 / No. 2 | Oktober 2018.

Maharani, I. (2014). Respon Pasar Atas Informasi Laba (Replikasi Ball Dan Brown 1968). ISSN: 23028556 E-Jurnal Akuntansi Universitas Udayana 8.1 (2014): 83-93.

Natalia, D., \& Ratnadi, N. D. (2017). Pengaruh Konservatisme Akuntansi Dan Leverage Pada Earnings Response Coefficient . 
E-Jurnal Akuntansi Universitas Udayana Vol.20.1. Juli (2017), 61-86.

Ratnasari, D. (2017). Pengaruh Persistensi Laba, Ukuran Perusahaan dan Default Risk terhadap Earnings Response Coefficient. Prosiding Akuntansi ISSN : 2460-6561 Volume 3 No 2.

Reyhan, A. (2014). Pengaruh Komite Audit, Asimetri Informasi, Ukuran Perusahaan, Pertumbuhan Laba Dan Profitabilitas Terhadap Kualitas Laba. JOM FEKON Vol. 1 No. 2 Oktober 2014.

Scoot, William R. (2009). Financial Accounting Theory. Fifth Edition. Canada Prentice Hall. Hal 154 .

Simamora, B., \& Herawaty, V. (2019). Analisis Faktor-Faktor Yang Mempengaruhi Corporate Social Responsibility Dengan Pertumbuhan Perusahaan Sebagai Variabel Moderasi. Seminar Nasional Cendekiawan ke 5 Tahun 2019 ISSN $(P)$ : 2460 - 8696 Buku 2: "Sosial dan
Humaniora" ISSN (E) : 2540 7589 .

Sulung, E. (2019). Pengaruh Kualitas CSR, Deafult Risk terhadap Earnings Response Coefficient.

Suwardjono. (2005). Teori Akuntansi: Perekayasaan Pelaporan Keuangan (Edisi III). Yogyakarta: BPFE

Tuhasanah, D., \& Nikmah. (2017). Pengaruh Corporate Social Responsibility Disclosure (CSRD) Terhadap Rasio Profitabilitas Dan Earning Response Coefficient (ERC). ISSN: 2303-0356 Vol 7 Jurnal akuntansi No.3, Oktober 2017, 1-16.

Wahyudi, T., \& Kadir, A. (2019). Pengungkapan Corporate Social Responsibility (Csr), Kualitas Auditor Dan Ukuran Perusahaan Terhadap Earnings Response Coefficient (Erc). Jurnal Manajemen Dan Akuntansi Volume 20 Nomor 1. 